\title{
ボラード状態のプロペラにより誘起される変動水圧について
}

\author{
黒部 雄三*・松田登**・右近 良孝**

\section{Fluctuating Pressure Induced by a Propeller in the Bollard Condition}

\author{
Yuzo KUROBE, Noboru MATSUDA and Yoshitaka UKON
}

\begin{abstract}
When a ship propeller operates at zero ship speed, known as the bollard condition, high pressure fluctuations are induced around it. In water of restricted depth pressure fluctuations could cause churning up of mud at the sea bottom and in some cases enviromental problems in harbors, canals and rivers. Since these phenomena are not fully understood and the qualitative prediction is difficult, it is necessary to study the fundamental nature of these fluctuations.

In this work, the pressure fields around the model propellers operating in the bollard condition were measured. Measured results are classified into three types of fluctuating pressures as follows :

(1) Periodic and low pressure fluctuations induced by the propeller blade thickness effect and the propeller loading.

(2) Random and high pressure fluctuations induced by the propeller-hull vortex.

(3) Unsteady and low pressure fluctuations induced by the propeller wake.

Pressures due to the propeller-hull vortex were found to be the highest, while pressures due to the propeller itself and pressures due to the propeller wake were found to have almost equal magnitude.

Extensive experimental data given in this paper are useful for predicting unfavorable phenomena caused by propellers operating under the bollard condition.

\section{1.はじめに}

現在、環境問題がますますクローズ・アップされており、船舶の運航による港湾や水路における環境影 響もその一つである。船舶を推進するプロペラは、発進や停船時に船尾周りで大きな水圧変動を起こすこ とが知られており、この現象が底泥の巻き上げばかりでなく、岸壁近傍や水路での洗掘等を起こす原因の 一つとして考えられる。しかしながら、船舶の発進、離岸時においてボラード状態で作動するプロペラが 周囲に及ぼす影響は充分把握されていない。この種の研究としては、プロペラ近傍の船体とプロペラの間 に生ずるプロペラ・ハル・ボルテックス・キャビテーション (PHVC) に関する報告があるが、必ずしもボ ラード状態の研究ではない ${ }^{(1)(2)(3)}$ 。従って、船舶の離岸、着岸時の環境影響を評価するためには、ボラード 状態のプロペラまわりの圧力場や流場の基本的な性質を把握することが不可久である。

本報告では翼数のみを変化させたシリーズ・プロペラについて、ボラード状態で作動するプロペラが誘 起する変動水圧を計測し、底泥の巻き上げや洗掘を評洒する上で必要なデータを得た。また、ボラード状 態のプロペラにより誘起される変動水圧を、(1)プロペラそのもの、(2)プロペラ・ハル・ボルテックス、(3)
\end{abstract}

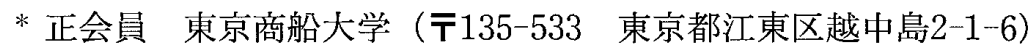

**非会員 運輸省船舶技術研究所（ $\overline{\mathbf{T}} 181-0004$ 東京都三鷹市新川6-38-1） 
プロペラ後流、という3つの要因別に整理、検討した。

\section{2. 供試プロペラおよび実験状態}

供試プロペラとしてコンテナ船用の翼数シリーズ・プロペ ラを使用した。主要目を表 1 に示す。模型プロペラ MPNo.232,233および192はピッチ比1.00は同じで、翼数 $Z$ のみ备3、4および5としたシリーズ・プロペラである。

本実験注 1 亿示す運輸省船舶技術研究所の大型キャビテ ーション試験水槽の第 1 計測部 (直径 $0.750 \mathrm{~m}$ 、計測部長さ $2.250 \mathrm{~m}$ ) で行った。プロペラの下方に海底にみたてた平板 (長 さ0.60m、幅 $0.35 \mathrm{~m}$ )を設置して計測を行った。計測装置を図 2 亿示す。平板には圧力計 （共和 PS- $2 \mathrm{KA}-\mathrm{M}$; 容量 $2 \mathrm{~kg} / \mathrm{cm}^{2}$ 、図中P.G.と表記） を11個セットし、プロペラ により誘起される压力を計 測した。プロペラは主プロ ペラ動力計 $(\mathrm{K} \& \mathrm{R}$ J26)に より駇動される。また、動 力計を上下流方向に移動す ることにより、圧力計とプ ロペラの位置関係を変更で きる。本実験ではプロペラ と海底との距離の影響を調 ベるため、プロペラ先端と

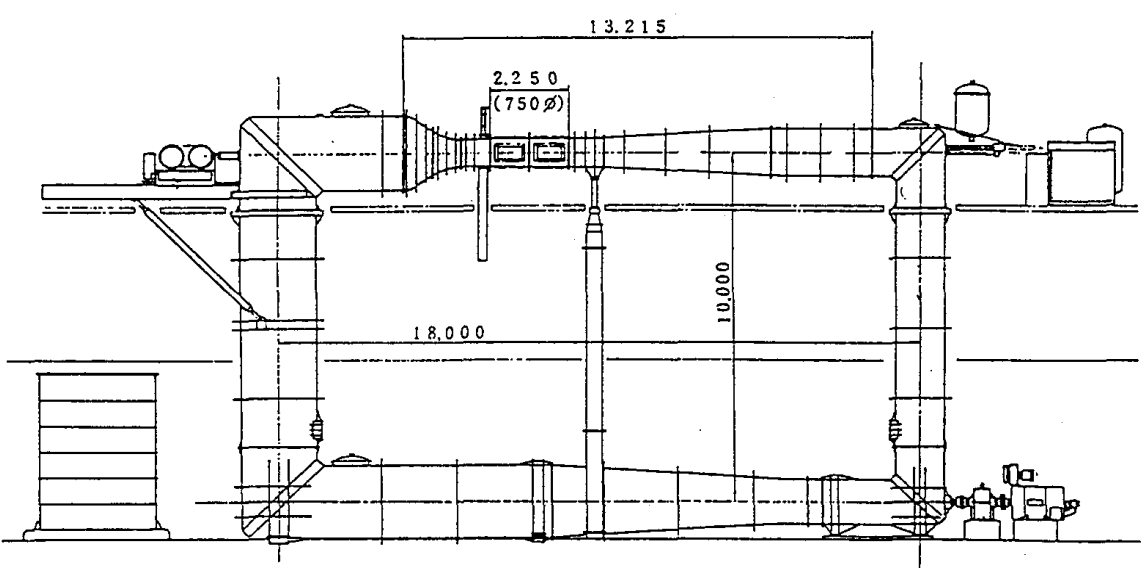

図 1 大型キャビテーション試験水槽（船舶技術研究所） 平板との距離(ティップ・クリアラン ス） $Z_{t}$ 変化させ、各プロペラによる変 動水压を計測した。 $Z_{t} / D$ は0.20から 0.38 であった。( $D:$ プロペラ直径)

本実験は閉塞型回流水槽の一種であ るキャビテーション水槽で行ったた め、インペラを駆動しなくてもプロペ ラ自身により起こされる後流や誘導速 度により計測部に流れが生じ、ボラー ド状態を長時間保つことができない。 この制限のため、設定プロペラ回転数 $n$ は10rps とした。前進率 $J\left(J=V_{a}\right)$ $n D ； \boldsymbol{V}_{a}:$ プロペラ前進速度、 $n:$ プ ロペラ回転数、 $D:$ プロペラ直径) が 0.2 以下となる状態では $30 \sim 40$ 秒程度 計測できた。プロペラの回転数を零の
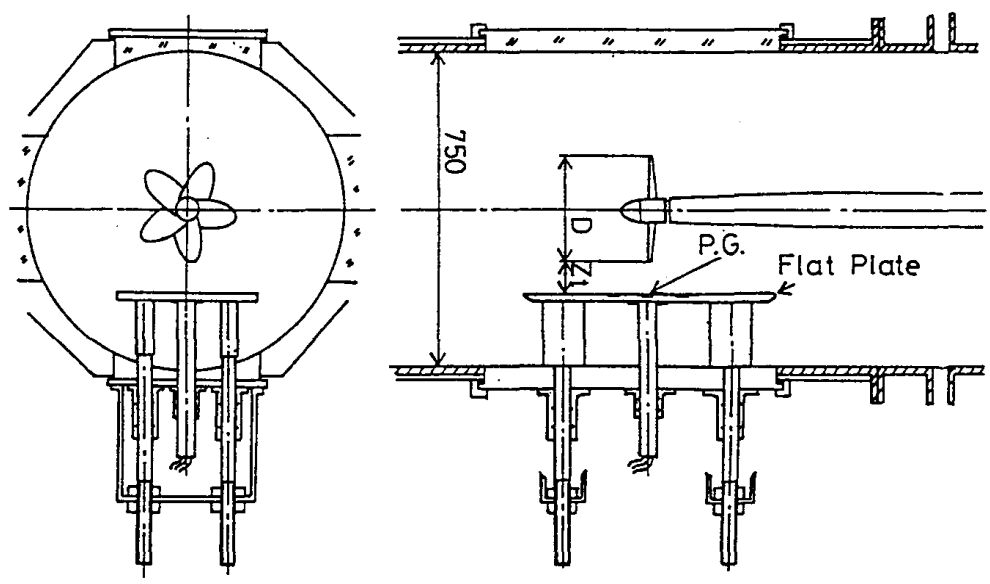

図 2 変動水圧計測装置

状態から ら0.8〜1.4rev/ $/ \mathrm{sec}^{2}$ の加速度で上昇させ、所定の回転数に設定した。設定後、プロペラによる流れの ため、プロペラ前進速度が $0.5 \mathrm{~m} / \mathrm{s}(J=0.2)$ になった時点で計測を終了した。解析は回転数設定後の計測 データの平均値により行った。 


\section{3. 実験結果}

今回計測されたボラード状態のプロペラにより誘起される変動水圧を、3つの成分に分けて、検討した。 すなわち、プロペラ近傍に生ずるプロペラそのものにより誘起される周期的な成分、プロペラ・ハル・ボ ルテックスにより起こされるランダムな成分、およびプロペラ後方域に生ずるプロペラ後流により起こさ れる成分である。それぞれの変動水圧について、計測結果およびその性質について述べる。

\section{1 プロペラによる周期的な変動水圧}

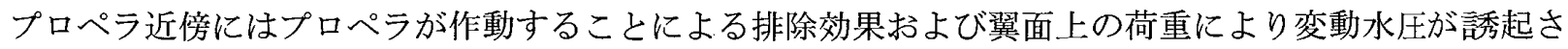
れる(1)。プロペラが停止している時の圧力をゼロとすれば、全体が負圧である翼数 $\times$ 回転数の基本周波数 (B.F.)成分をもつ水圧変動となる。

プロペラ翼数のみを 3,4 および 5 翼に変化させた時の、 $Z_{t} / D=0.2$ でのB.F. の変動压力振幅係数 $K_{p z}$ $\left(K_{p z}=P_{z} / \rho n^{2} D^{2} ; P_{z}: B . F\right.$. 成分の変動水圧振幅) の左右船方向 $(Y)$ 抢よび上下流方向 $(X)$ 分布を図 3 (a) と (b) に示す。平板上、プロペラ軸心に平行で、プロペラ翼端直下の点を $X 、 Y$ の原点とした。翼数が 増えるに従い、変動水圧振幅は減少する。 5 翼プロペラによる变動水圧は 3 翼プロペラと最大值で比較す ると、約40\%小さくなる。

図中の 2 種類の破線と一点鎖線はHUSEの方法 (4)を改良した方法による計算值である。HUSEの 方法では、プロペラ自身を吹き出し分布でおきか えて排除効果による変動水圧を、揚力を渦分布に おきかえてプロペラ荷重度による変動水圧を計算 し、両者を加えて全体の変動水圧を求めている。 本報告では、プロペラ荷重度による変動水圧を計 算する際に用いるプロペラ翼断面上の揚力分布 を、HUSEの方法での平坦な形状から、高荷重時 に見られる翼前縁にピークを持つ直角三角形状に 変えて計算を行った。水圧振幅の実験值と計算值 との違いは最大でも $20 \%$ 以内におさまっている。 計算値と実験值の違いは翼数の増えた方が少な い。

また、ティップ・クリアランス $Z_{t}$ 変えた場合 の変動水圧振幅 $K_{p z}$ の変化を図 $4(\mathrm{a})$ と $(\mathrm{b})$ に示 す。ティップ・クリアランスが増加すると、これ に逆比例して変動水圧振幅は減少する。図 4 (b) に見られる様にプロペラが逆転した時の変動水圧 は、正転時と比べてわずかに減少する。計算值む、 ティップ・クリアランスの増加と共に変動水圧の 減少する傾向を定量的にも良くとらえている。

3.2 プロペラ・ハル・ボルテックスによるラ ンダムな変動水圧

プロペラ荷重度が大きくなり、ティップ・クリ アランスが小さくなると、プロペラ近傍に逆流域 が生ずる。そして、平板とプロペラの間に強い、 間欠的なライン・ボルテックス(プロペラ・ハル ・ボルテックス、PHVと称する。)が発生する。 PHVが起こるかどうかは、プロペラの幾何形状に はあまり依存せず、プロペラ荷重度とティップ・ クリアランスの大きさによると言われている

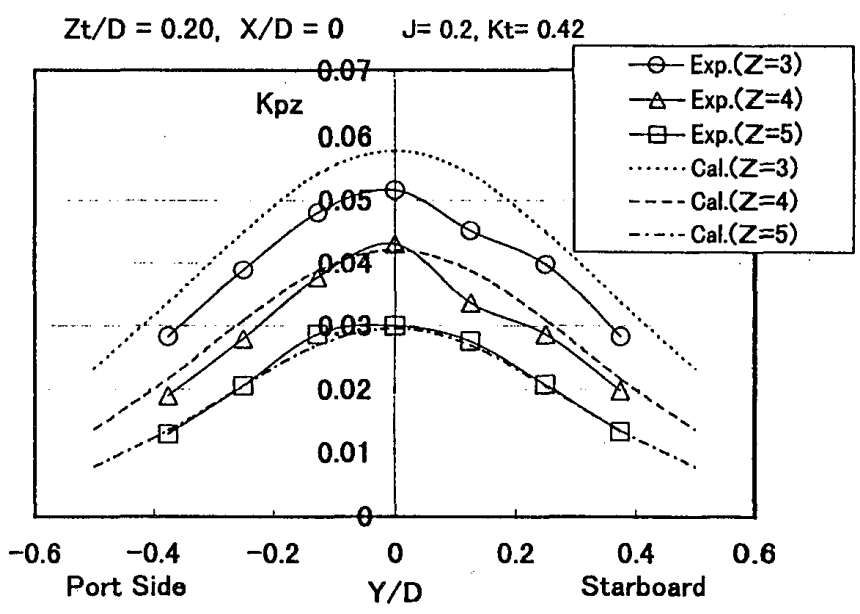

図 3（a）プロペラによる変動水珪振幅分布 (左右輆方向分布)

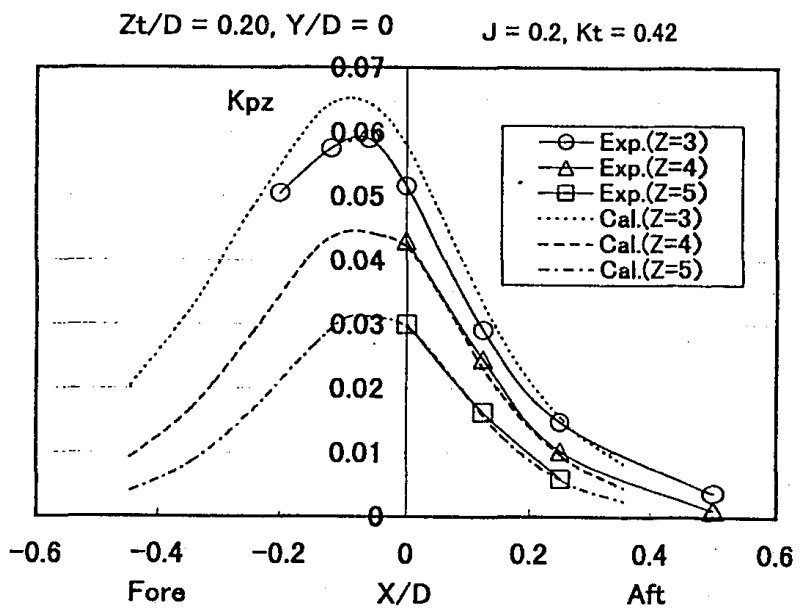

図 3 (b) プロペラによる変動水圧振幅分布 （上下流方向分布） 
正転， $X / D=0, Y / D=0$

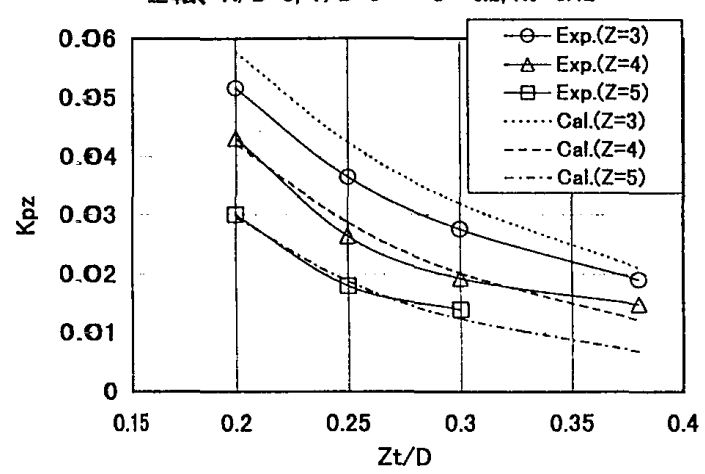

図 4(a) 変動水圧振幅のティップクリアランス による変化 (正転の場合)

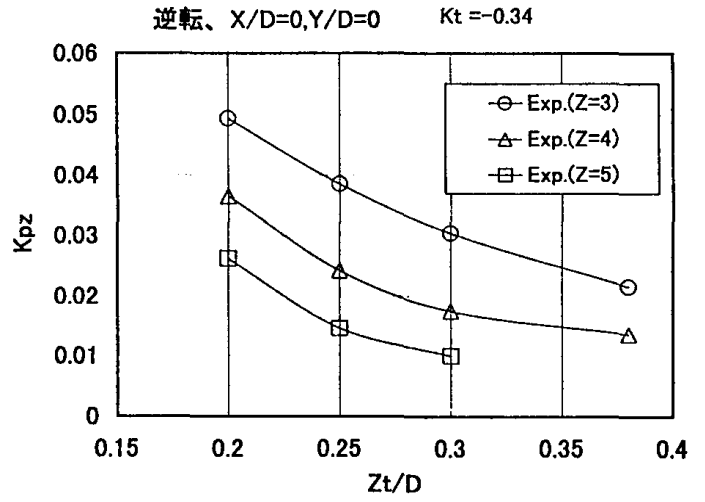

図 4（b） 変動水圧振幅のティップクリアランス による変化(逆転の場合)

(2)(3)。図 5 中に、本実験で、プロペラ直下 $(X / D=$ $0, \quad \boldsymbol{Y} / D=0)$ にPHVの発生した状態を $\bigcirc, \triangle$, 口で示す。佐藤により示されたPHV発生限界線 ${ }^{(3)}$ の内側にあり、予測と一致する。図の傾向から、 プロベ荷重度が増加しても、PHVの発生するテ イップ・クリアランス $Z_{t} / D$ には限界陋があるよ うに推測される。

プロペラ荷重度 $C_{t}\left(C_{t}=8 T /\left(\pi \rho D^{2} V_{a}^{2}\right)\right.$; $T:$ プロ゚ラ・スラスト)が23〜27の状態では、テ

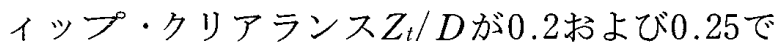

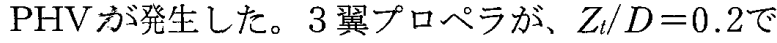
作動する時のプロペラ直下 $(X / D=0, Y / D=$

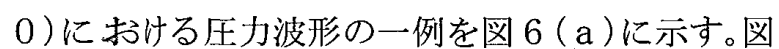

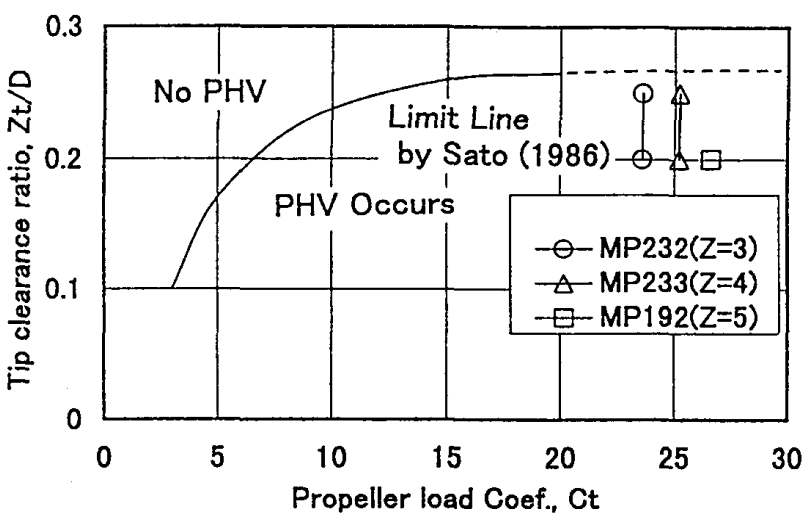

図 5 プロペラ・ハル・ボルテックス (PHV) の 発生範囲 の左端の数字は圧力計の出力電圧值で、右端の数 字は䨌圧值から求めた変動圧力振幅係数である。スパイク状のパルスがPHVにより誘起された負圧であ る。この圧力波形を時間方向に拡大したものを図6(b)に示す。正弦波状の波形が3.1節で述べたプロペラ そのむのによる周期的な変動水圧である。PHVによる圧力はその周期的変動水圧より約 3 倍から 10 倍大き く、不規則に発生する。PHVによる圧力パルスの最大波高值 $P_{v}$ の無次元值 $K_{p v}\left(K_{p v}=0.5 P_{v} / \rho n^{2} D^{2}\right)$ を図 7 ( a ) と (b)に示す。プロペラ直下で最も大きな振幅のPHVによる変動水圧が発生している。プロぺラ逆転 時には、正転時に比べ、PHVが起こりにくいことが観測された。

以上の結果から、3.1節のプロペラそのものによる変動水压值および後述の、プロペラ後流による変動水 圧值と比較して、PHVにより誘起される変動水圧の格段に大きいことがわかる。しかし、PHVそのものが

$\mathrm{Z}=3 \quad \mathrm{Zt} / \mathrm{D}=0.2, \mathrm{X} / \mathrm{D}=0, \mathrm{Y} / \mathrm{D}=0$

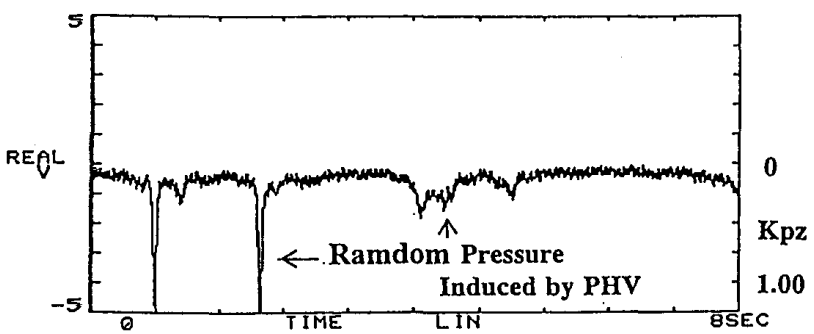

図6（a） PHVによる压力波形例
$\mathrm{Z}=3 \quad \mathrm{Zt} / \mathrm{D}=0.2, \mathrm{X} / \mathrm{D}=0, \mathrm{Y} / \mathrm{D}=0$

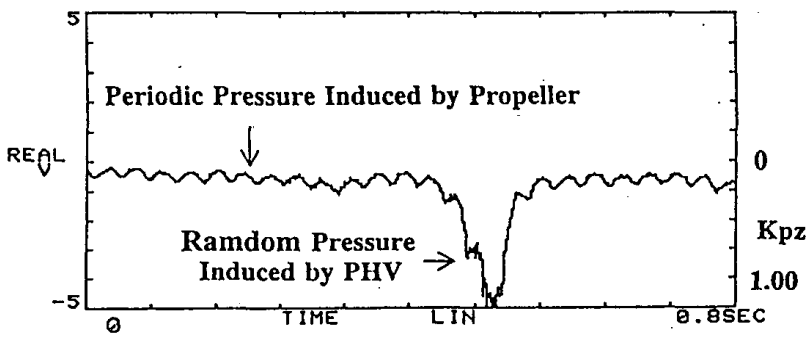

図 6（b） PHVによる圧力波形例（時間軸拡大） 
非定常性の強い現象であり、PHVによる変動圧力値の定量的予測には、さらなる研究が必要である。

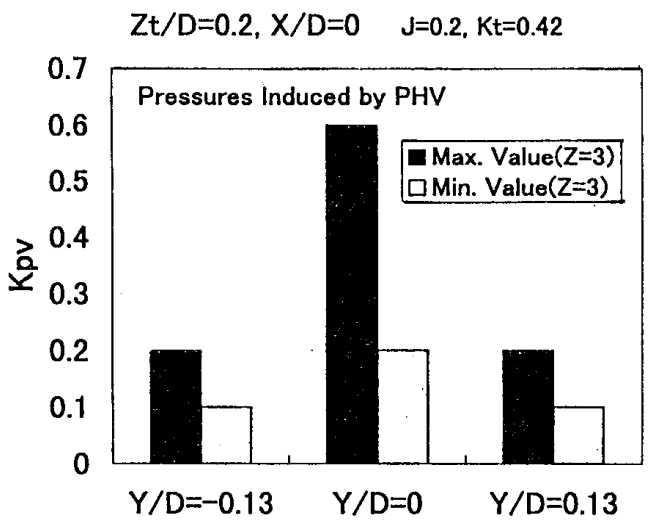

図 7 （a） PHVによる変動水圧波高分布 ( 3 翼プロペラ)

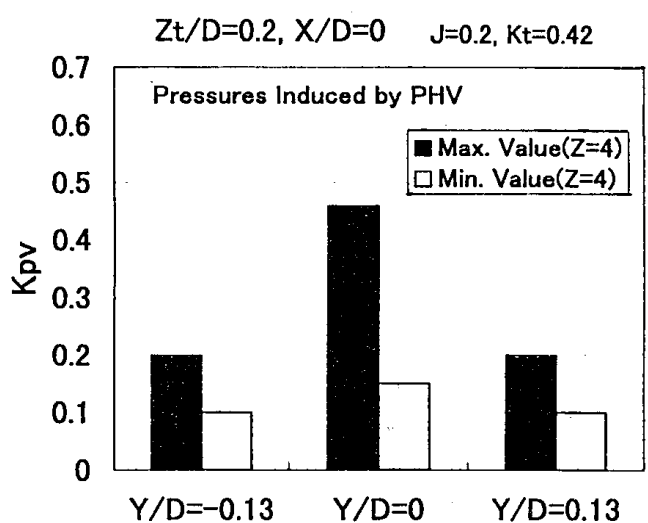

図 7 (b) PHVによる変動水圧波高布 (4翼プロペラ)

\section{3 プロペラ後流による変動水圧}

作動するプロペラ後方には後流渦が存在し、ボラード状態では粘性影響により後流渦は拡散し、広範囲 な乱流域が形成されると考えられる。水面をプロペラ上方の $Z / D=0.3$ 付近をで下げた状態で、プロペラを ボラード状態で作動させると、プロペラ直径の 3 倍 $(X / D=3)$ 程度下流冺ら水面が擋乱されることが観測 される。この変動水圧の大きさを調べるため、今回は $X / D=1 \sim 5$ および $Z / D=0.05 \sim 0.38$ 範囲での変 動水圧を計測した。

計測された圧力波形の一例を図 8 に示す。これは 3 翼プロペラより誘起される圧力を、 $Z_{t} / D=0.2$ で $X /$ $D=5$ の位置で計測した結果である。圧力波形を高速フーリエ解析した結果を図 9 に示す。卓越した周波数 のない、広い周波数成分をもっていることがわか る。

高速フーリエ解析での変動圧力振幅のオーバー オール值 $P_{w}$ を無次元化した值 $K_{p w}\left(K_{p w}=P_{w} /\right.$ $\left.\rho n^{2} D^{2}\right)$ のプロペラ後方 $(X)$ および下方 $\left(Z_{t}\right)$ 分布 を図10(a) と（b)に示す。プロペラによる計測値 の違いは、ピッチ比が同じであるため、僅かであ った。変動水圧振幅の流れ方向の分布において、 プロペラの下流 $X / D=3$ 付近でピークがあり、上 記の観測結果と一致する。しかし、深さ方向の分 布では $Z_{t} / D=0.05 \sim 0.38$ の範囲でティップクリ アランスが大きくなっても変動水圧振幅はほぼ一 定である。後流渦の拡散による乱流が変動水圧の 起振源となっているものと考えられるが、この現 象についての説明はできない。

実験では、有限な面積の平板を広い海底に見立 てて、圧力を計測している。プロペラそのものに よる圧力は、プロペラの幾何形状と荷重度のみに 関係しており、プロペラの作動状態さえ把握して おけば、平板の大きさは計測值に影響を及ぼさな い。をた、PHVは平板とプロペラとの流力的相互 干渉により起こるが、その相互干渉はプロペラ近 傍に限られるため、本実験での平板の大きさで充

$\mathrm{Z}=3 \quad \mathrm{Zt} / \mathrm{D}=0.2, \mathrm{X} / \mathrm{D}=5$

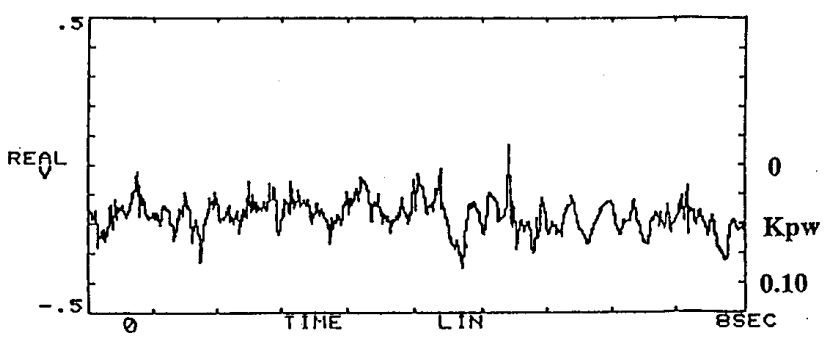

図 8 プロペラ後流による圧力波形例

$\mathrm{Z}=3 \quad \mathrm{Zt} / \mathrm{D}=0.2, \mathrm{X} / \mathrm{D}=5$

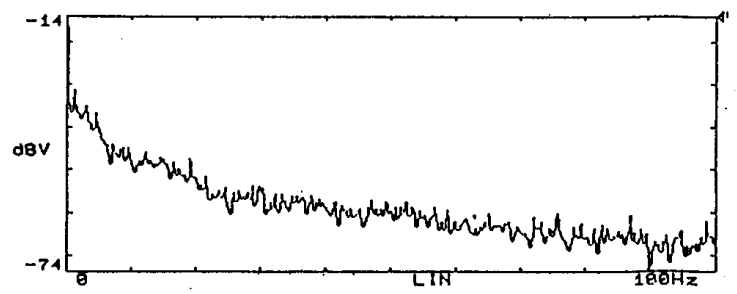

図 9 プロペラ後流による変動水压の周波数分布 


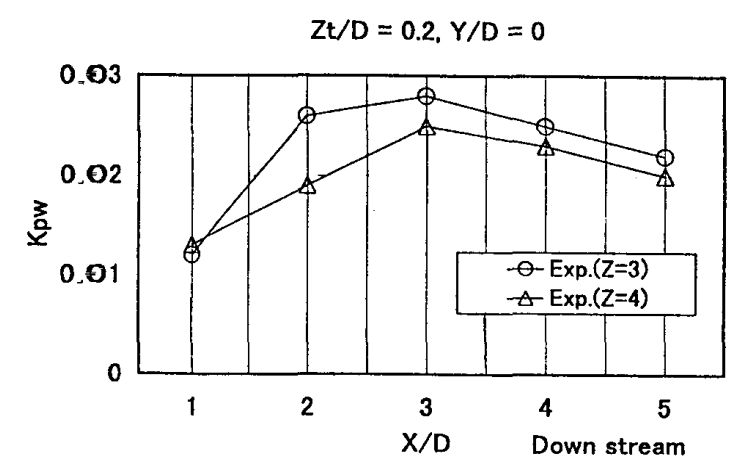

図10（a）プロペラ後流による変動水圧分布 (上下流方向)

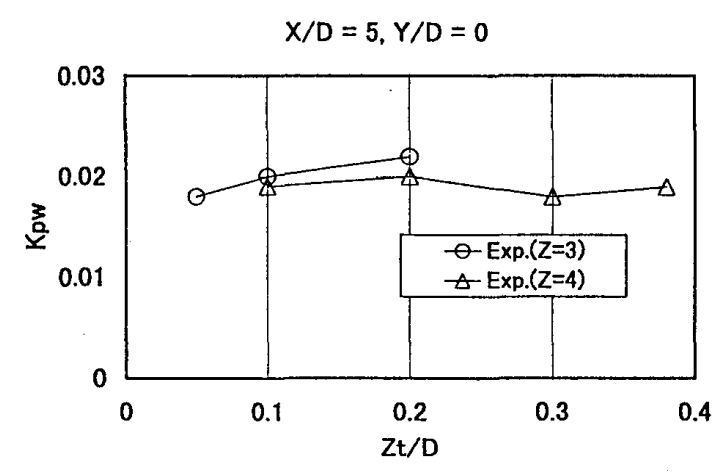

図10 (b) プロペラ後流による変動水圧分布 （深さ方向）

分と考える。しかし、プロペラ後流による圧力に関しては、使用した平板に比べて広い乱流域が形成され るため、乱流域の様相が平板と海底では違ってくるので、平板の大きさの影響はあると思われる。プロペ ラ後流による変動水圧の解明及び予測には、プロペラ後方流場の詳細な調查が必要であるう。

\section{4. 考 察}

本計測結果を活用して、ボラード状態のプロペラによる底泥巻き上げの予測を試みた。一例として、装 備プロペラのピッチ比 $H / D$ が約1.0の高速コンテナ船(船長; $L_{p p}=200 \mathrm{~m}$, 排水量 ; $\Delta=36,000 \mathrm{t}$, 喫水; $d=10.5 \mathrm{~m}$, 定格回転数; $N=120 \mathrm{rpm}$,プロペラ直径; $D=7.4 \mathrm{~m}$, ピッチ比 $; H / D=1.03$, 翼数 $; Z=4)$ をとりあげる。その船のプロペラが、水深 $12 \mathrm{~m}$ の港内で、ボラード状態で作動した場合の変動水圧値を、 3 章の実験結果を使い、算出してみる。

ボラード状態でのプロペラ回転数 ; $N=60 \mathrm{rpm}$ 、ティップクリアランス比 $; Z_{t} / D=0.20$ として算出する と、下記のようになる。

(1)プロペラそのものによる変動水圧振幅 $\quad 150 \sim 300 \mathrm{~kg} / \mathrm{m}^{2}$

(2)P HVによる変動水圧振幅 $1,200 \sim 2,900 \mathrm{~kg} / \mathrm{m}^{2}$

(3)プロペラ後流による変動水圧振幅 $\quad 150 \sim 200 \mathrm{~kg} / \mathrm{m}^{2}$

振幅 $2,600 \mathrm{~kg} / \mathrm{m}^{2}$ 、周期 $3 \mathrm{sec}$ 変動水圧により、海底砂地盤の液状化の起こることが報告されている(5)。 すなわち、土は液状化して懸濁状態となり、引張抵抗が期待できない状態になる。このことから、この例 の様な作動状態では、PHVによる底泥の巻き上げや洗掘は十分起こりらると思われる。一方、プロペラそ のものやプロペラ後流による変動水圧では液状化は起こりにくいものの、液状化した底泥の巻き上げは、 変動水圧が連続して誘起されることから、弱いながらも広範囲にわたることが予想される。

\section{5.まとめ}

ボラード状態でのプロペラによるプロペラ近傍の変動水圧を計測し、検討した。その結果、以下のこと がわがった。

（1）プロペラ・ハル・ボルテックスにより誘起される変動水圧が、プロペラそのものによる周期的変動 水圧や、プロペラ後流によるものより格段に大きい。港内や水路での底泥巻き上げや洗掘を避ける ためには、まずプロペラ・ハル・ボルテックスを発生させない様にすることが効果的である。

(2) プロペラそのものによる変動水圧は、ボラード状態でもHUSEの方法を修正した方法に基づく計算 により推定することが可能である。

(3) プロペラ後流による変動水压の振幅は、ピッチ比1.0のプロペラでは、プロペラ直径の 5 倍以内の範 团で、プロペラそのものによる変動水圧の振幅と同程度であった。

本論文で得られた計測値は、底泥巻き上げの発生を予測する上で有効に活用できるものと考える。 


\section{参 考 文 献}

(1) Huse,E. : Propeller-Hull Vortex Cavitation, International Shipbuilding Progress, Vol.19, No.212, 1972.

(2) Nishiyama,S. : An Experimental Study on PHV Cavitation, 西部造船会会報, 第71号, 1986.

(3) Sato,R. et al. : Observation of Flow on a Horizontal Flat Plate above a Working Propeller and Physics of Propeller-Hull Vortex Cavitation, International Symposium on Propeller and Cavitation, Wuxi, 1986.

(4) Huse,E. : The Magnitude and Distribution of Propeller-Induced Surface Forces on a Single-Screw Ship Model, Norwegian Ship Model Experiment Tank Publication, No.100, 1968.

（5）善功企：波浪による海底地盤の液状化現象，港湾技術研究所講演会講演集，1990.12.

\section{質 疑 応 答 \\ 内田 誠(神戸商船大学)：}

(1) 実験ならびに計算におけるキャビテーション数はいくつでしたか。

（2）変動水圧の推定計算には、どのような方法を用いられましたか。また、ボラード状態のための修正 ではどのような修正をされましたか。

黒部雄三 : ご討論いただき、ありがとらございます。

(1) 実験は水槽を大気開放の状態で行いましたので、キャビテーション数 $\left(\sigma=2\left(P_{0}-e\right) / \rho n^{2} D^{2}\right)$ は35 程度でした。計算でもキャビテーションや流れの剥離は考えていません。

（2）プロペラを吹き出しや渦分布でおきかえるHUSEの方法を一部修正して用いました。ボラード状態 における翼断面揚力分布を平坦な形状汃ら、直角三角形状に修正しました。

庄司邦昭(東京商船大学)：プロペラ・ハル・ボルテックスによる変動水圧の発生周期、頻度はどの程度で したか。

黒部雄三：ご討論いただき、ありがとうございます。プロペラ・ハル・ボルテックスはランダムに発生し ますので、水压波高、頻度共ばらつきがあります。例えば、翼数 3 のプロペラの場合、平均すると 1 、 2 秒に 1 回の頻度で起こりますが、周期的ではなく、プロペラまわりの流れの状態に敏感に影響される 様です。 